\title{
1. Federal rivers: a critical overview of water governance challenges in federal systems
}

\author{
Dustin Garrick, George Anderson, \\ Daniel Connell and Jamie Pittock
}

Sustainable management of rivers, lakes and aquifers is crucial to the well-being of people and the environment (MEA 2005). Farms, cultures, industries, cities and nations have been established along the banks of major river systems. Demand for freshwater and other riverine commodities has increased with population growth and economic development, while climate change and extreme events disrupt hydrological processes and water supply. As a consequence, the World Economic Forum (2013) has identified water supply shocks among its top societal risks for the past three years running. Effective governance of fresh water is therefore a foundation of sustainable and equitable societies.

In this context, the Organisation for Economic Co-operation and Development (OECD) (2012) has identified the global water crisis as a crisis of governance and policy fragmentation. Increasingly, water management challenges involve complex interdependencies between sectors, upstream and downstream jurisdictions and stakeholders at the local, state, national and international levels. These interdependencies pose coordination challenges across political borders - both within and between countries. Federal countries distribute authority between national and state jurisdictions, which complicates water management tradeoffs within river basins shared by multiple territories. This book examines the experience of nine different federal political systems and China in addressing challenges of river basin and water management.

Federal river systems (see Figure 1.1) are major basins within or shared by one of the world's 28 federal countries (Anderson 2008, 2010; Garrick et al. 2013). Shared river basins are a major test of federal systems of governance. Effective management is not the mandate of one level of governance: all levels of governance have key roles, though these will vary from federation to federation. It can be expected that federalism will produce 


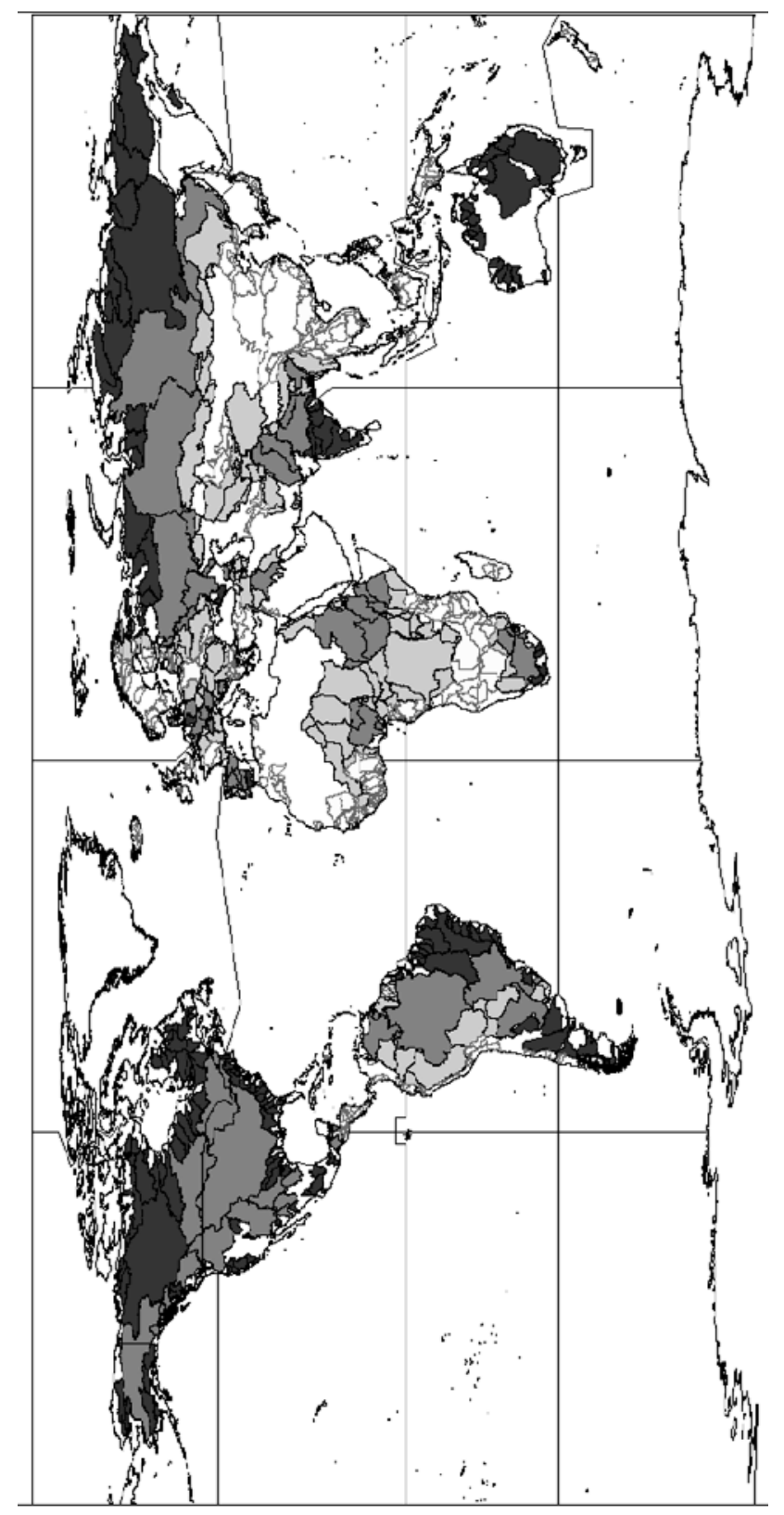

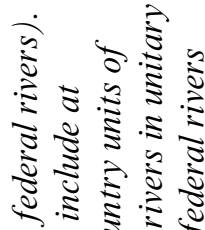

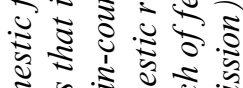

ป.

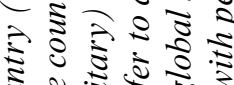

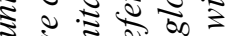

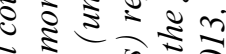

ฟ

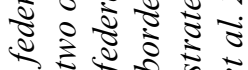

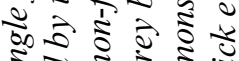

2.

ป

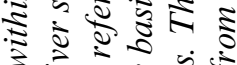

क人

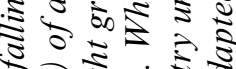

क.

方产

:

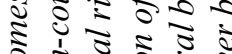

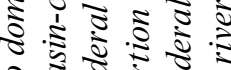

$\therefore 5 \frac{2}{2}: \frac{1}{2}$

ปิ)

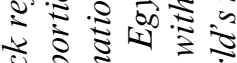

डै ह

จ ฐ

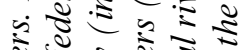

ఫए

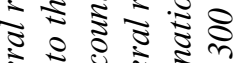

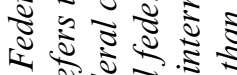

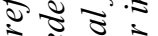

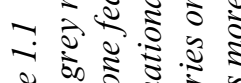

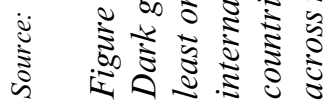


different patterns of decision-making and implementation than unitary regimes and that this will affect outcomes. This is a major issue shaping the chapters in this book.

While there is an extensive literature on the management of river basins across international borders, prior research about river basin management within federal countries has largely focused on individual basins and countries. This volume addresses a number of issues that are key to understanding interjurisdictional water allocation and management in federal countries. What are the salient water management challenges in federal rivers? How does federal design affect the capacity and effectiveness of integrated approaches to water management across multiple jurisdictions? Answering these questions requires an understanding of how federations allocate responsibilities for rivers and how they balance the rights of independent jurisdictions with the need for integrated management. These issues have become more pressing due to the spread of federalism across a diverse range of geographic settings, as well as the growing prevalence of sub-national water conflicts across jurisdictional boundaries.

Equitable risk sharing and conflict resolution are difficult in federal rivers even when constitutional provisions coordinate power sharing and mechanisms are available to manage interjurisdictional disputes over water. The architects of these different federal systems in some cases have elaborated fairly clear allocations of responsibility for river basin management, in other cases not; even when the allocation of responsibilities is clear, the political will and circumstances may make cooperation difficult, with limited coordination of information, weak joint institutions, perverse incentives and insufficient or inappropriate infrastructure across multiple jurisdictions. Fortunately, there are also happier stories and this volume tries to understand the drivers in both cases.

Two overarching themes cut across the country chapters: (1) the increasing need for integrated water resources management and water security in federal rivers, and (2) the capacity of federal water management arrangements to respond to these needs.

\subsection{INTEGRATED WATER RESOURCES MANAGEMENT AND WATER SECURITY}

Integrated water resources management has received extensive attention as a form of water governance (see Schlager and Blomquist 2008 for a critical review). Following the 1992 International Conference on Water and the Environment in Dublin, global water experts have advocated integrated water resources management (IWRM) - a package of reforms designed 
to address connections between land and water and encourage participation by multiple stakeholders in water planning (see Conca 2006). ${ }^{1}$ River basins have been upheld as the natural unit of water planning and management due to upstream-downstream interdependencies and the connection between land use and water within catchment and basin boundaries. Drought, flooding and increased competition have also prompted calls for river basin management to reduce risks and make tradeoffs at a whole-ofbasin scale. However, IWRM has proven elusive in practice. Progress has been limited and contested, leaving the promise of river basin approaches often unfulfilled (Schlager and Blomquist 2008, Connell 2010, 2011).

The divergence of political and biophysical boundaries - across countries and within federations - has been a prime challenge for IWRM. This mismatch makes it more difficult to manage multiple, often conflicting, goals across upstream and downstream jurisdictions within transboundary rivers. Therefore, water policy prescriptions for integrated water resources management are inherently political and have required collective action at multiple scales from water users and state governments to national governments and international river basin commissions and treaty organizations.

Climate change and competition for variable water supplies superimpose the challenge of water security on top of issues of institutional fragmentation in federal rivers. Assumptions of stationarity have been rejected, which means that water management decisions cannot be based on the notion that the future will resemble the past (Milly et al. 2008); the timing, quality and volumes of water flows may change as well as the severity of extreme events like floods and droughts. In this context, water security is increasingly seen as a fundamental goal of integrated water resources management to ensure the availability of water for human development and ecological health along with the capacity to manage and adapt to multiple risks and climate hazards (Grey and Sadoff 2007).

Closed river basins - where downstream commitments are not met due to upstream development - illustrate upstream-downstream interdependencies and the need for a coordinated response in the context of increasing hydroclimatic risks (Falkenmark and Molden 2008). Australia is a striking example that illustrates the connected challenges of integrated water resource management and water security in a federal country facing climate variability and change. Despite the recognized need for integrated river basin management, Australia has experienced entrenched barriers to basin-wide integration within a federal system where powers are divided. The 'millennium drought' (1997-2010) in the Murray-Darling Basin of Australia provided a preview of our changing world (Pittock and Connell 2010). During this prolonged drought, competition for scarce and variable water supplies intensified between production and ecological sustainability. 
Australia's drought was then followed with the wet extremes and floods of 2010-13 that replenished wetlands and aquifers but had mixed impacts, including lost lives and economic damage in Queensland, flooded crops and black water events for Murray cod (Maccullochella peelii). Water reforms in the Murray-Darling have responded with episodic basin-wide efforts to share risks and benefits that have been marked by high transaction costs and unsatisfactory compromises due to tension between state governments and between the states and federal authorities (Connell 2010, 2011).

The specific issues differ across river systems - for example, semi-arid, subtropical, monsoonal and temperate river systems - and levels of economic development. River basin strategies must therefore be adapted to local and regional contexts. Although river management responses to multiple tradeoffs will invariably involve different pathways across diverse contexts, there is a large scope for mutual learning. Even where there is a recognized need for multi-jurisdictional river basin management, there are many questions about the design of federal arrangements for water management, including: opportunities and limits for river basin governance institutions, the role of subsidiarity (itself a subjective concept) in assigning responsibilities between orders of government, roles of nongovernment versus government institutions, the merits of polycentric versus more unitary governance structures, and incentives and penalties for implementation of common river management measures. These are the second theme of the forthcoming chapters.

\subsection{FEDERAL ARRANGEMENTS FOR WATER MANAGEMENT}

Water management in federations is severely complicated by the political partition of the country and the division of powers between the federal and constituent unit governments (Anderson 2008, Elazar 1987). As noted above, the logical management area for water planning and allocation - a major river basin - typically has very different boundaries from those of the constituent units of the federation. Thus federations can have great difficulty adopting cooperative and functional approaches to water policy, especially in situations of severe conflicts caused by competition among multiple values, exacerbated by hydroclimatic variability and associated risks tied to drought, flooding and systemic tradeoffs.

This mismatch between political boundaries and river basins in federal countries poses special challenges for (1) systemic cost and benefit sharing and (2) conflict management between the states of the federation. The literature on international waters has identified the importance of 
international treaties and river basin organizations to promote cooperation and manage conflicts in shared waters (Wolf 2007, Schmeier 2010). Federal systems often confront similar challenges with conflict management and risk sharing to those arising in international waters despite having an institutional structure and legal regime to share powers. Federal rivers also differ from much studied international rivers in another way: while they face some similar opportunities and constraints on risk sharing and conflict resolution, they operate in a constitutional context in which there is both divided sovereignty, as between nations, and united sovereignty, as in unitary regimes. The precise mix and dynamics of these internal arrangements varies greatly across federations.

Federal constitutions allocate varying degrees of authority to their constituent states to manage challenges that span multiple jurisdictions (Bednar 2008). In dealing with river basins that cross state boundaries, they must deal with divided geographic responsibilities (state-to-state) as well as functional responsibilities (federal versus state governments). Each federation is different in its constitutional arrangements, political dynamics and objective challenges in river basin management. What they have in common is the need to operate a complex system of polycentric governance arrangements where there may be strong imperatives to address river management issues that involve several governments.

The global extent of federal rivers invites comparative analysis about federal arrangements to manage shared water resources in many different contexts. A comparative perspective can yield insights about the global picture of federal rivers, the water management challenges they face and the diverse water policy and river basin management approaches developed in response. Authors of the country-level overview chapters develop a concise analysis of the federal system of water management in terms of the type and salience of water challenges, on the one hand, and the characteristics of the federal arrangements for water management, on the other, including the constitutional provisions related water management and the roles of different levels of government and key actors (courts, legislature and so on). The challenges of integrated water resource management and water security are presented in this federal context to identify the primary water issues, institutional mechanisms for interjurisdictional water sharing and conflict resolution, and fiscal arrangements.

\subsection{OVERVIEW OF THE BOOK}

This volume develops a comparative perspective and set of case studies to assess federal systems of water management. Authors applied multiple 
analytical frameworks to develop insights at the river and country level. Theoretical approaches and analytical frameworks include: federalism, fiscal federalism, polycentric governance and the politics of scale. These approaches provide a rounded, and complementary, perspective on water management in federal systems and are introduced in more depth by chapter authors.

The introduction has drawn on the other chapters to outline the crosscutting questions and themes structuring the case studies of water security, river basin management and federalism. Chapter 2 (Pittock) presents a global overview of water security challenges posed by climate change, focusing on institutions needed to coordinate water supply for people and healthy riverine ecosystems in multi-jurisdictional rivers - both nationally and internationally. This overview provides global context and also lessons from Australia's experience in the Murray-Darling Basin, which is on the leading edge of experience with climate-related water security challenges in an historic context of failed policies and ineffective coordination at the whole-of-basin scale.

The rest of the book comprises 17 case studies across ten countries: Australia, Brazil, Canada, China, India, Mexico, Pakistan, South Africa, Spain and the US. The case studies offer an overview of water policy and management in each federation, with a clear presentation of the framework within which water policy has been developed and managed, including the legal authorities, fiscal arrangements and institutional structure for water management. The case studies are organized geographically to offer a global tour across the Americas (Chapters 3-8), Spain (9-10), South Africa (11-12), South Asia (13-15), China (16-18) and Australia (19). Chapter 20 examines human security challenges tied to water management in cross-border regions of multiple federal countries. The concluding chapter draws on the country-specific cases to reflect on lessons and emerging trends in the politics and policy of water management within federal political systems (Chapter 21).

In some countries, two case studies are offered with a case study providing a country-level overview and a second case study analysing river basin management in an important basin within the country. The river basin level case studies include the interstate rivers of the western US, the Saskatchewan River in Canada, three river basins in Mexico, rivers of the Lowveld region of eastern South Africa, the Narmada River in India, the Pakistan portion of the Indus River, the Murray-Darling, and three chapters on rivers in China - a non-federal country with some emerging federal-like characteristics influencing water management. These case studies consider the water security and integrated water resources management challenges for the river basin, along with a series of focal questions: 
- Why is the chosen federal river important?

- What are perceived to be the main risks and threats to water security for the major stakeholders?

- What are the ongoing controversies and unresolved issues in the basin? How have they evolved over time?

- What are the legal and policy frameworks and institutional structure, and how are outcomes determined in practice?

- How do the federal and state governments interact within this structure, and how have these interactions evolved?

- What institutional responses are used to promote change and resolve conflicts?

In this context, each river basin case study considers the factors that enable or constrain effective river basin management in federal systems.

\subsubsection{Americas}

The chapters from the Americas start in the US - the oldest federation. The water management challenges vary from water pollution in the eastern US to water scarcity and climatic variability in the irrigation-dominated region west of the 100 th meridian. These contrasting water challenges have historically prevented a unified, national framework for river basin management, despite federal legislation to manage water quality (for example, the Clean Water Act). Gerlak (Chapter 3) traces the evolution of state-federal relations in water management across multiple periods, highlighting the need for a historical perspective to understand the allocation of powers, functions and capacities shaping contemporary river basin management efforts. She shows that contemporary arrangements are marked by 'pragmatic federalism' with collaborative partnerships and coordination across and within state and federal levels in response to integrated water management problems and processes, such as watershed planning.

Chapter 4 (led by Schlager) grounds the American experience in the interstate rivers of the western US to illustrate the role of transboundary compacts in building adaptive capacity to manage historic and projected climate variability and change. A review of multiple interstate rivers identifies ways in which states and the federal government build adaptive capacity through proportional allocation rules and interstate commissions to administer compact agreements governing rivers shared by multiple states.

Canada is richly endowed with water, so that the major issues of water management have typically had more to do with water quality and manag- 
ing ecosystems than with water scarcity. The federal regime is one of the most devolved in the world and water resources are largely the responsibility of the provinces; the federal government has some significant legislative powers touching water, as well as its spending power, but has tended to use them with restraint. Water politics has tended to have relatively low visibility and to be essentially regional in character. Canada's experience is therefore marked by a more decentralized federal system of water management. Saunders (Chapter 5) demonstrates how the federal government's reticence to exercise its water management powers and other levers of influence has constrained basin management regimes.

The Canadian interstate (inter-provincial) basins with the most acute management challenges are the Mackenzie and Saskatchewan river basins east of the Rockies. The Mackenzie-Athabasca has major issues around water quality and withdrawals because of the oil sands; given their national importance, the federal government has been drawn into the debate and environmental studies. There was agreement in 1969 among the three Prairie Provinces and federal government on water apportionment for the Saskatchewan basin, but this has not provided the mechanism to address some emerging apportionment challenges. The Saskatchewan River of western Canada therefore illustrates the consequences of this fragmentation in Chapter 6 (Horbulyk), where Canada's model of cooperative federalism has failed to build adequate resilience to manage water scarcity (particularly across provinces), droughts, and nutrient loading in Lake Winnipeg. The three provinces operate quite independently of one another in their water management planning.

Mexico is comparatively more centralized in its federal design and has undergone a reform process to decentralize powers and functions in water management over the past two decades. The country spans a range of challenges from the industrializing, semi-arid north, which has a long history of irrigation development, to urbanization in central Mexico and rural development of the subtropical south. A common challenge across these multiple regions is the lack of provision of water for the environment. Barrios (Chapter 7) outlines Mexico's federal system of water management under the 1992 National Water Law, which encouraged decentralization despite the establishment of a powerful national water agency (Comision National del Agua). This chapter emphasizes the challenges of establishing a coherent national policy framework and strengthening river basin organizations despite continuing tensions among the local users, states and federal government. Against this backdrop, new models of water management have been attempted to secure water for the environment through pilot efforts led by World Wide Fund for Nature (WWF) in the Rio Conchos (a subbasin of the Rio Grande/Bravo), the 
Copalita-Zimatan-Huatulco river basins and the San Pedro Mezquital River - each of which have included a mix of national and local-indigenous communities to define and manage ecological reserves.

Like Mexico, Brazil's vast territory presents diverse challenges. An innovative federal system of water management has emerged in Brazil in response to disparate water security risks and a constitutional division of powers between rivers designated as 'federal' (which cross state boundaries) and state rivers (which do not). Chapter 8 (led by Coelho) chronicles the reform process leading to the establishment of the National Water Resources Management System in Brazil, which favours economic tools and decentralized participatory management within river basin committees at multiple levels. A recent national 'pact' is attempting to harmonize management across states by using financial incentives to build capacity and empower particular regions of Brazil.

\subsubsection{Spain}

Spain confronts water stress and intensifying competition for variable water resources in a semi-arid environment. It has a complex multi-level system of water management involving river basin authorities, autonomous communities (states), the national government as well as the supranational water management provisions of the European Union. Chapter 9 (Albiac) documents the deep historical roots of contemporary federalism in Spain dating from the medieval kingdoms of northern and eastern Spain. Constitutionally, responsibility for river basins is vested at the national level for basins that cross the boundaries of multiple autonomous communities. Rivers that fall entirely within one autonomous community are managed by that community. At the national level, the contemporary system of water management is based in a 1985 law. River basin authorities are arms of the national government (for river basins that traverse internal boundaries) but provide the venue for users (particularly irrigation) to make decisions and plans. The European Union exerts increasing influence, principally through the 2000 Water Framework Directive establishing a goal of good ecological status and a corresponding process of river basin planning and management to incorporate EU standards into national and sub-national law.

López-Gunn and De Stefano (Chapter 10) examine contemporary water security challenges in Spain to illustrate changing state-federalEU relationships under the competing pressures of decentralization and Europeanization of water management. This analysis shows how the definition of water security changes with scale from a more local focus on water storage and irrigation for food production balanced against the 
European Union focus on ecology and water quality. Four case studies on water security and decentralization in federal rivers of the Tajo-Segura, Ebro, Jucar and Guadalquivir demonstrate a three-level game across state, federal and European influences on river basin management planning under the Water Framework Directive.

\subsubsection{South Africa}

South Africa does not call itself 'federal', but the 1996 Constitution has the character of a relatively centralized federation. The Water Act of 1998 reflects the values of the new constitution and the imperative of the transition to democracy after the apartheid era; an important part of its water reform was the need to redress historic inequities and the creation of a domestic and ecological water reserve. Muller (Chapter 11) reviews this water reform and the conscious effort to retain powers and functions at the national level and avoid 'balkanization' at the river basin level. Technical working groups on water supply and sanitation advised a two-level system with a strong national competency to back local and regional delivery. Implementation has been more constrained, however, particularly in the establishment of catchment management authorities to undertake planning, and for the national government to step in if the authorities fail to do so. The South African model avoided the fragmentation of powers and functions to allow infrastructure development and inter-basin tradeoffs.

Chapter 12 (led by Pollard) examines devolution and cooperative governance within the South African context. The establishment of catchment management authorities has proven more difficult to achieve than expected, and exposed challenges of building capacity for effective water governance at more local scales. The experiences of the eastern Lowveld region rivers have illustrated the need to combine formal allocation of powers and functions with informal institutions, legal pluralism and social learning at and within the catchment level. This local experience in a centralized federal system of water management highlights the need for appropriate incentives and self-organization to achieve the objectives of the 1998 Water Act.

\subsubsection{South Asia}

Asia's experience can be divided between the South Asia federations of Pakistan and India and the Eastern Asia experience in China, which although not a federation, has relevant multi-layered dynamics that show the spread of some federal-like practices even within this authoritarian society.

With its vast population, India's federation (Chapters 13 and 14) shows 
tremendous diversity - in the size of its federal units (the largest state being over 200 million people, the smallest union territory less than 100,000), in its languages and cultures, and in the development of its regions. Hydrographically, it has both deserts and the rain soaked north-east, but the defining character of the country is the monsoon, which is vital for its overwhelmingly rural population. Increasingly, its politics reflect this diversity, with powerful regionally based parties and strong state governments. Constitutionally, the states have the main responsibility for water and the Union government has never been able to impose a coherent national water policy or even to assert itself in relation to inter-state waters.

A case study of the Narmada River (Chapter 14) illustrates water allocation conflicts among four riparian states. The water dispute tribunal and associated river basin control authority have struggled to manage competing demands and have largely neglected groundwater and land use change. These challenges highlight the need for data sharing between states and an increasing coordination role for the national ministry of water resources to improve understanding of basin hydrology and incorporate data on groundwater use and land use change into updated interstate water sharing agreements.

Pakistan (Chapter 15) has only four provinces, but three of them and over 90 per cent of the population lie within one watershed, the Indus basin. This basin has been subject to massive engineering works, both to deal with the separation of river flows between India and Pakistan and to develop the world's largest contiguous irrigation network managed under a federal arrangement. The Constitution gives the greater role on water management to the federal government, but in practice major decisions on water are so regionally sensitive that the provinces are always deeply involved. After an extended period of inter-provincial tensions around shares, irregular water supplies and power outages, there was an historic Water Apportionment Accord in 1991, agreed by the four provinces with the strong support of the federal government. The implementation of the accord has been hobbled by some optimistic assumptions, different interpretations and weak technical support. The recent constitutional changes, which include strengthened roles for the high level forum of heads of government as well as for the Senate, offer some possibilities for more political dialogue, but a series of major innovations will be needed if the country is to address the challenges it faces.

\subsubsection{China}

This volume also includes three chapters on China. China is not a democracy, nor is it federal. The constitution plays a minor role in relation to 
internal governance. However, it is a vast country that necessarily has different regional interests. Therefore, some have suggested that China is quasi-federal and exhibits 'behavioural federalism'. The factors that are producing this result are described in Chapter 16 (Silveira). Using the Pearl River as an example he explains how the national government decision in the 1980s to promote economic development by devolving considerable powers to key provinces selected as policy pilots resulted in an effective handover of responsibility for many of the activities that determine water quality, probably the greatest single water problem in southern China. Water pollution has been a notable by-product of economic development in China. But the policies needed to improve water quality unavoidably affect millions of small and large businesses and clash with provincial policies - and central directives - promoting economic development. The national government has the undoubted legislative power to intervene but the capacity to do so effectively may be in question where powerful stakeholder groups with strong polluting interests have developed in the various provinces.

The complexity of managing in this system characterized by the internal politics of a Communist Party that is increasingly permeable to certain external pressures resulting from economic and social development is investigated further in Chapter 17 (Ke Jian), which examines the case of Tai Lake in eastern China. Here the national government had to intervene in 2007 after the city of Wuxi with one million inhabitants had its drinking water cut off for over a week because of severe pollution. (This event drew attention to a persistent problem which had been intensifying for many years.) The Tai Basin, surrounded by two provinces and Shanghai Municipality and home to just under 40 million people, is one of the most industrialized regions in the country. Despite drastic action by the central government, which closed thousands of polluting businesses and industries at the height of the crisis, the development of a water governance regime that can control pollution without stifling provincial dynamism continues to be an unresolved challenge in the Tai Basin and beyond.

In addition to the challenges resulting from cross-border water pollution, water scarcity also causes conflicts between provincial governments in China. In Chapter 18, Lan Fang examines conflicts between Shaanxi and Hubei provinces which are both being required by the national government to contribute to the middle route of the vast south-north project which will divert water from three points along the Yangtze River to the north of China. At issue is the need to share the costs, direct and indirect, and the compensation being provided by the regions in the north that will benefit. It is an intense struggle between donating and receiving 
provinces and municipalities with the national government arbitrating the conflict. Provincial governments have the same formal institutional status as national departments so to a significant degree it is a struggle between equals within a bureaucratic and party system rather than a disagreement between junior and seniors within an authoritarian hierarchy.

\subsubsection{Australia}

Chapter 19 (Connell) provides a report on the ongoing struggle about water policy in Australia's Murray-Darling Basin (MDB). As of December 2012 the national government is implementing a comprehensive basin plan backed by over $\$ 12$ billion in new investment in infrastructure and water entitlements for the environment. The history of river management in the MDB provides an interesting study in the effective limits of financial power in a federal system. Financial power rests overwhelmingly with the federal government but it has been repeatedly frustrated over the decades by the determination of state governments to use their greater knowledge and administrative capacity in relation to water issues to promote their own often conflicting goals. This chapter places the current debate within its historical context and discusses the new set of institutional arrangements that are emerging in a rather different form than was originally intended by policy makers in the national government but which could prove quite robust and moderately effective.

\subsubsection{Comparative Perspective and Conclusions}

The final section includes a comparative chapter (Maganda) on human security in cross-border regions of North America, Europe and South America. These cross-border environments involve challenges of human insecurity in meeting basic needs including drinking water and sanitation to support development. The geographic distance of these cross-border regions from the hubs of central governments poses special challenges for federal water management systems. Human security challenges in crossborder regions demonstrate the need for national governments to build capacity in local communities, while respecting their autonomy, similar to the insights emerging from South Africa.

The closing chapter (Anderson) reflects on how the constitutional and political nature of federal systems come together with highly variable water management challenges (even within different regions of the same federation) to affect the policy and institutional response to water management, including in various river basins. 


\section{PRELIMINARY REFLECTIONS}

The studies in this volume suggest that federal systems have a major advantage in addressing river basin management compared to international rivers: the existence of a national level of government injects a major new actor into conflicts amongst states over the equitable distribution of costs and benefits. However, the legal and financial levers that the national governments have can vary a great deal, given different constitutional arrangements, and the political motivation of national governments to intervene will also vary depending on the national importance of the river basin management issues as well as the political costs and benefits for the government party or parties. Thus in at least some of the cases discussed in this book national governments have proved reluctant to play that role; for example in Canada, the issues of river basin management have not been seen to be so important as to require a major intervention by the federal government, whereas in Spain, in contrast, the issues have been so politically difficult that the national government has played a cautious role in recent years. Even in cases where national governments have been more willing to assert national priorities, as in South Africa, they have still proven difficult to impose in practice. This is even the case in China where the national government is struggling to manage cross-border water quality issues. Probably the most determined example of strong national government intervention discussed in the book is that of Australia where the latest round of reform has resulted in a new institutional rearrangement which now places the national government at the centre of water policy development in the Murray-Darling Basin. It appears that a federal system makes it easier for regional or sectional interests to block change (reform) than do non-federal systems, but it must be noted that federalism is often deeply embedded in the nature of the society - even with its difficulties, it is not an 'optional' choice.

For the researchers contributing to this book, water security and integrated water resources management provided a common reference point. One way to develop a list of threats to water security is to examine the many ways in which people use or relate to water. These could be biophysical, social, cultural, economic, environmental or political. If a particular relationship is important to people, then it probably contains within it dependencies and vulnerabilities that can become significant sources of insecurity under particular circumstances. According to the OECD the primary source of threats to water security comes from inadequate governance systems and the lack of integration, the processes that are used to decide who will get water in what condition, when, where and how: in other words the relationships between different groups of people that 
determine their access to water or vulnerability to the dangers it creates (such as having to live on the flood plain because they are poor). The goal of improved water security and integrated water resources management implies betterment for society as a whole but the 'fair' distribution of costs, benefits and compensation is crucial if that is to be a reality. A major question for students of federalism, as well as studies of water management, is how federal systems affect the outcomes of struggles about such questions.

\section{NOTE}

1. The Global Water Partnership refers to IWRM as a process which promotes the coordinated development and management of water, land and related resources, in order to maximize the resultant economic and social welfare in an equitable manner without comprisiming the sustainability of vital eco-systems.

\section{REFERENCES}

Anderson, G. 2008. Federalism: An Introduction. Toronto: Oxford University Press.

Anderson, G. 2010. Fiscal Federalism: An Introduction. Toronto: Oxford University Press.

Bednar, J. 2008. The Robust Federation: Principles of Design. New York: Cambridge University Press.

Conca, K. 2006. Governing Water: Contentious Transnational Politics and Global Institution Building. Cambridge, MA: MIT Press.

Connell, D. 2011. The Role of the Commonwealth Environmental Water Holder. In Q. Grafton and D. Connell (eds), Basin Futures: Water Reform in the Murray-Darling Basin. Canberra: ANU E-press.

Connell, D. 2010. Managing Climate Variability in Australia, South Africa, United States and Spain, CWEEP Research Paper 10-12.

Connell, D. 2007. Water Politics in the Murray-Darling Basin. Sydney: Federation Press.

Elazar, D. 1987. Exploring Federalism. Tuscaloosa, AL: University of Alabama Press.

Falkenmark, M. and Molden, D. 2008. Wake up to realities of river basin closure. International Journal of Water Resources Development [ISI], 24(2): 201-215.

Garrick D, De Stefano L, Fung F, Pittock J, Schlager E, New M, Connell D. 2013 Managing hydroclimatic risks in federal rivers: a diagnostic assessment. Phil Trans R Soc A 371: 20120415.http://dx.doi.org/10.1098/rsta.2012.0415

Gerlak, A.K. 2006. Federalism and U.S. Water Policy: Lessons for the TwentyFirst Century. Publius: The Journal of Federalism, 36(2): 231-257.

Grey, D. and Sadoff, C.W. 2007. Sink or swim? Water security for growth and development. Water Policy, 9: 545-571.

MEA (Millennium Ecosystem Assessment) 2005. Ecosystems and Human Well- 
being: Wetlands and Water Synthesis. Washington DC: World Resources Institute.

Milly, P.C.D., J. Betancourt, M. Falkenmark, R.M. Hirsch, Z.W. Kundzewicz, D Lettenmaier and R.J. Stouffer. 2008. Stationarity is Dead: Whither Water Management? Science, 1 February 2008: 319(5863): 573-574.

Pittock, J. and Connell, D. 2010. Australia Demonstrates the Planet's Future: Water and Climate in the Murray-Darling Basin. International Journal of Water Resources Development, 26(4): 561-578.

Schlager, E. and Heikkila, T. 2011. Left High and Dry? Climate Change, Common-Pool Resource Theory, and the Adaptability of Western Water Compacts. Public Administration Review, 71(3): 461-470.

Schlager, E. and Blomquist, W. 2008. Embracing Watershed Politics. Boulder, CO: University Press of Colorado.

Schmeier, S. 2010. Governing International Watercourses - Perspectives from Different Disciplines. Hertie School of Governance - Working Papers, No. 53, August 2010.

Wolf, A.T. 2007. Shared Waters: Conflict and Cooperation. Annual Review of Environment and Resources, 32: 3.1-3.29. 